\title{
Feeding (On) Geopolitical Anxieties: Asian Appetites, News Media Framing and the 2007-8 Food Crisis
}

\section{Qian Gong and Philippe Le Billon}

\begin{abstract}
This paper analyses the role of news media in (re)producing geopolitical narratives of food insecurity in relation to the 2007-08 global food price spike. News content and textual analysis suggests that the media's representation of the food price spike is partly framed by Western geopolitical anxieties of the 'threatening rise of Asia', and features 'fast growing' Asian appetites among the main culprits of the crisis. Seeking to explain the widespread circulation of such representation, this paper analyzes media-source relationship within the context of market-driven journalism, and suggests that the changing role of news media has in turn contributed to a rapid and uncritical circulation of elite-based interpretation of, and neoliberal geopolitical approach to, food security. The paper points at the importance of critical enquiries into geopolitical representations of food insecurity and of opening media space for a 'counter-geopolitics of food security'.
\end{abstract}

\section{Keywords}

Food security, 2007-08 food crisis, news media, framing, Asia 


\section{Introduction}

This paper draws on theoretical insights from critical geography to analyze media coverage of the 2007-08 food crisis. Focusing on reports from worldwide major broadsheet English language newspapers we seek to demonstrate how these news media cast blame on increasing food demand by Asian countries, and more specifically China, suggesting that 'rising Asian appetites' constituted a global threat to food security. The paper starts with a discussion of global food security in connection with the 2007-08 food price spike, and considers key geopolitical interpretations of the causes of and solutions to food security discussed in policy and intellectual domains. The next section reviews the theoretical debates around critical geopolitics and normative functions of the media, as well as more specific discussions on media framing of geopolitical narratives. We then outline the research methods before turning to the core analysis, examining the discursive constructions by the news media to create narrative frames on the problems, culprits, and solutions to the food crisis.

\section{Food Security, Geographical Assumptions and Geopolitics}

Food prices sharply increased in 2007, affecting consumers in many parts of the world. Prices peaked in June 2008 before declining in the context of the financial crisis. ${ }^{1}$ Expressing deep concern for the state of global food security, the Food and Agricultural Organization (FAO) estimated that an additional 75 million people had become 
chronically hungry people in 2007 as the result of price increases compared to the 2003-5 period, bringing the total to 923 million people. ${ }^{2}$ Commonly referred to as the 'global food crisis', the food price spike had triggered protests and social unrest in more than thirty countries. On 20 April 2008, the UN Secretary General Ban Ki-moon warned that: 'The crisis could result in a cascade of others...become a multidimensional problem affecting economic growth, social progress and even political security around the world'. ${ }^{3}$ The prominence and potential implications of the food crisis generated numerous debates about its causes, consequences and solutions among a wide spectrum of actors. Major causes in debates included increasing fuel costs, poor weather in some major producing regions, financial speculation, and rising food consumption in Asia. ${ }^{4}$ Beyond these 'conventional' and 'direct' causes some critics pointed at the deep-seated structural origins of the food crisis, including the 'industrialization of agriculture, the liberalization of food and agricultural markets and the rise of food empires', as well as 'inequalities in global agro-food systems' ${ }^{5}$

Despite emerging criticism of the structural inequalities of the food crisis, mainstream policy responses to the 2007-08 food crisis were largely based on three recommendations: 'a technical solution to increase productivity; greater liberalization of agricultural markets and interventions to assist the very poorest' ${ }^{6}$ As such the post 2007-08 crisis agro-food governance did not challenge the prevailing status quo and, for some, would thus fail to address existing inequalities in global agro-food systems and the complex conditions of food insecurity. ${ }^{7}$ To problematize the failing, yet still dominant agro-food governing system based on the 'global neoliberal order', critical geopolitical scholars, among others, 
stress the importance of interrogating geopolitical framings of food security that reinforce the hegemonic agro-industrial model dominating the world food system. ${ }^{8}$

Food security has long been part of national security and geopolitical strategies. In part because the 2007-08 food price spike triggered 'food riots' in countries considered as 'food insecure' such as Haiti but also Mexico, the 'food crisis' provoked renewed concern over the geopolitical dimensions of food security. ${ }^{9}$ Traditionally, national security and geopolitical strategies formed around food security have to a large extent been premised upon a 'North and South divide' geographical assumption. Although the 2007-08 food price spike was thought to have affected a great number of urban poor in (de)industrialized countries of the North, many governments still regarded food security primarily as a concern confined to low-income countries in the South where $75 \%$ of food insecure people reside. ${ }^{10}$ The interpretations of food security as a problem largely existing in a classically conceived 'Global South', but also increasing as a threat to the comfort and safety of populations in the 'Global North' have been used as a political resource to formulate food aid programs playing a central role within international food security strategies. ${ }^{11}$ Historically food aid was used instrumentally as a mechanism to dispose food surpluses from the Global North, as well as to contain hunger as a political, economic and social threat from developing countries in the Global South. ${ }^{12}$ Despite evolvements in the food aid programs including adaptations in delivery methods and integration of sustainability and development elements, geopolitical and economic concerns have persisted in the global food aid architecture. ${ }^{13}$ 
In recent years, concerns re-emerged in the discussions of food security threat posed by rising economies in Asia, manifested in a geographical assumption based on a new East/West division after the Cold War era. China with its rising population and demand for food has been constructed as a food security and environmental threat, generating much neo-Malthusian fear in geopolitical discourses in the West, in particular in the US. ${ }^{14}$ As Boland argues, Lester Brown's influential book Who will feed China?: WakeUp Call for a Small Planet has generated much debate about China’s increasing demand for food both internationally and in the US. The China 'threat' became a policy-making concern for the US that deployed its intelligence community to investigate claims made in Lester Brown's book. ${ }^{15}$ Recent overseas investments by China, South Korea and Middle East firms and sovereign funds, notably in Africa, further fed the fears of resource insecurity manifest in the 'global land grab' discourse in the West. ${ }^{16}$

Securitized narratives of food crisis based on 'neo-Malthusian predictions of an imminent descent into socio-political chaos amidst growing global food supply-demand imbalances' often call forth liberal humanitarian interventions that focus on technical fixes and liberal markets. ${ }^{17}$ Such solutions constitute a big part of the securitized neoliberal approach to food security adopted by national governments, inter-governmental organizations and transnational food corporations. In the meantime, globalization creates 'heightened interdependencies and vulnerabilities to dangers across the globe', ${ }^{18}$ rendering state intervention and protection even more important. Many argue, however, that this dominant neoliberal approach has resulted in entrenched structural inequality between the North and South, and deepened the dependency of the latter on the former. ${ }^{19}$ Over the 
years, emerging criticism of the dominant geopolitical framing of food security has presented some challenges for the global agro-food governance system. ${ }^{20}$ Some of the alternative movement (e.g. food sovereignty) constituting part of the 'alternative geopolitical arrangement' have challenged the 'hegemonic policies of food security', ${ }^{21}$ but are still in need of recognition by major food security institutions. ${ }^{22}$

\section{Critical Geopolitics and Media Framing}

Widespread debates over the 2007-8 'food crisis' among governments, policyorganizations, research institutes and the media have demonstrated the connection between 'formal/practical geopolitics' and 'popular geopolitics'. ${ }^{23}$ Over the last 20 years, a number of critical geopolitical studies have analyzed various popular geopolitical sites including films, newspapers, diasporic publications and magazines, and have explored the connection between 'practical geopolitics' and 'popular geopolitics' ${ }^{24}$ Some have found that media content works ideologically to reinforce dominant geopolitical narratives and frames. For instance, during the Cold War, media discourse on famine in Ethiopia during the mid-1980s reflected an anti-Communist geopolitical theme. ${ }^{25}$ The popular American magazine Reader's Digest was found to use Cold War geopolitical framings to contrast democratic USA and the evolving 'dangers' arising from the Soviet Union and communism. ${ }^{26}$ More recently, British broadsheet newspapers between 2000 and 2007 'tend(ed) towards a rather simplistic binary between well-intentioned West and amoral, greedy and coldly indifferent Chinese' in their coverage of China's foreign developments in Africa, ${ }^{27}$ largely reflecting a new geopolitical discourse premised upon 
the perceived threat from China. Even mainstream media, however, can also help to disrupt and challenge 'Western geopolitical scripts', thereby contributing to 'antigeopolitics' or 'counter-geopolitics' narratives, as in the case of some media coverage of wars in Bosnia. ${ }^{28}$ The above research shows that geopolitical framings can structure, as well as be challenged by, media scripts. In turn, the media scripts can (re)produce and circulate geopolitical understandings as well as unsettle them.

On a normative level, and from a (neo)liberal perspective, the basic functions of the media in political communication include providing a 'marketplace of ideas', informing and enlightening citizens, and acting as public watchdog in democratic societies. ${ }^{29}$ In ideal situations, the media provide a wide range of political perspectives to ensure that different geopolitical discourses can be brought into the public domain. The media should also have unbiased, neutral and balanced representations of local, national and global events to inform the public, instead of providing a platform to make the 'controllable geopolitical abstractions' favored by 'intellectuals of statecraft' visible to the public. ${ }^{30}$ Journalistic practices often differ, however, in particular in war and conflict scenarios in which geopolitical narratives are mostly noticeable, whether the media support or challenge dominant foreign policies and their geopolitical reasonings during humanitarian crises, or whether the media serve as “"mediators” for, "watchdogs” of, or "embedded within institutionalized geopolitical power"', depends much on the nuances in, and dynamics of, media-policy interaction such as policy un/certainties and control of information by governments, as argued by Robinson. ${ }^{31}$ 
The representations of geopolitical interests by news media is problematic not only because of external factors, such as policy environment and political/military censorship, but also because of factors internal to the craft of news-making, including 'existing structures for understanding the world, professional practice, organization imperatives and personal biases of journalists'. ${ }^{32}$ News-making often involves a framing process in which 'some aspect of a perceived reality' is selected in order to 'promote a particular problem definition, causal interpretation, moral evaluation and/or treatment recommendation'. ${ }^{33}$ Recent changes in public communication including the rise of political public relations further blurred the boundaries between politicians and journalists, ${ }^{34}$ two key groups of players who formulate and legitimize/popularize geopolitical reasonings in the public domain. Pinkerton furthers Sparkes' argument maintaining that many journalists have become 'geo-pundits' who are 'sustained as master storytellers who deploy sensationalism and particular news framing to "move" audiences in particular ways', ${ }^{35}$

Another important factor of problematic media representation, although less emphasized by critical geopolitics scholars, is market-driven journalism practice and its impact on the quality of news. Using the example of Reader's Digest, Joanne Sharp points out that the commercial media industry may think differently than the political and strategic communities and offer political 'knowledge' to their readers as 'a commodity'. ${ }^{36}$ The 'different thinking' is essentially underpinned by a 'media logic'- 'a strategy that the media use to maintain their relationship with a mass audience on which they depend for their economic survival ${ }^{37}$ - which has also led to desktop journalism and Churnalism 
emphasizing on speed, sensation, eventness and exclusiveness. ${ }^{38}$ In the meantime, political institutions and civil societies also increasingly adapt to 'media demands, media logics and media perspectives on politics itself' - a process called 'mediatization' ${ }^{39}$ Both groups, media and politicians, now work with the same set of news values to jointly produce political messages. The coupling of 'mediatization' and the practice of desktop journalism which often links to reduction, simplification and tabloidization is likely to lead to fast and uncritical circulation of public relation-mediated, elite-based interpretation of geopolitical events in popular culture.

Despite, or rather because of these problematic practices, news media are powerful institutions in shaping public perceptions. Political communication scholars have found strong empirical evidence for the ability of news media in shaping political agenda, influencing foreign policy and public opinions. ${ }^{40}$ Within the context of increasingly 'converged' political sphere ('high' culture) and popular sphere ('low' culture) ${ }^{41}$ in which media constitute, shape and legitimate political agenda including foreign policies, ${ }^{42}$ it is important to scrutinize the processes of articulation of geopolitical reasonings in popular culture - in this case framings of food security in the context of a 'global food crisis'.

\section{Methodology}

This analysis of the framing of the 2007-08 food price spike by news media, and the role of news media in (re)producing geopolitical narratives of food insecurity, is based on a 
quantitative and qualitative analysis of media texts. The quantitative analysis consisted of content analysis, a commonly used research method for studying media frames as content analysis provides 'an objective, systematic quantitative description of the manifest content of communication'. ${ }^{43}$ The construction of the coding framework used an operational definition of frame elements drawn from Entman's theory, according to which frames normally perform the following functions: problem definition, causal analysis, moral judgment, and remedy suggestion. ${ }^{44}$ Based on this, four frames were coded: main event frame (problem definition), culprit (causal analysis), victim (moral judgment), solver and solution (remedy suggestion). Each frame contained sub-frames that embodied different aspects emphasized by the news stories within the frame. The 'event frame' provided problem definition of the food crisis. The 'culprit' frame addressed the actor/factors causing the global food crisis. The 'victim' frame identified people/party presented as the victim by the media, and the 'solver' and 'solution' frame identified the actors/actions for resolving the crisis. The unit of analysis was the news story.

The LexisNexis database ( 'Major World Newspapers' group) was used to collect news covering the 2007-08 global food crisis. ${ }^{45}$ As the predominantly Anglo 'Major World Newspapers' group does not include any newspaper titles from China and India, two emerging economies often referred to in the news media, an additional set of news articles were collected from the state-owned China Daily (in English) to provide more insight into how food security discourses were constructed by the rising economies, and how such discourses might compete with those of the Anglo news media. Keywords 
'food crisis' was used to search the LexisNexis database. ${ }^{46}$ Search results returned 504 news items and many were irrelevant to the 2007-08 global food crisis analyzed in this study. Manual searches were then conducted within the results and eventually 372 articles (1 May 2007 - 31 December 2008) were selected. ${ }^{47}$ Another 39 news stories concerning global food crisis from the China Daily within the same time period were searched and accessed from its online database. Altogether 411 news articles were collected from both databases for content analysis and coded with SPSS software. The chosen time periods broadly covered the duration of the 2007-08 crisis, and the analysis of the media coverage during the broad period was hoped to provide a full picture of the ebb and flow of the media attention. Following the content analysis, a textual analysis of news stories was undertaken to analyze the narrative structures, discourses and sources of the media to investigate how news media produced, re-produced and circulated the key frames of the 2007-08 global food price spike.

\section{Media Framing of Global Food Crisis: China and India to Blame?}

The 2007-08 food prices spike started approximately from early 2007 and ended in mid 2008. ${ }^{48}$ The media coverage of the price spike and crisis peaked in April - July 2008, and dwindled quickly afterwards. The peaks of coverage by 'Major World Newspapers' group (Figure 1) in April, May, June and July coincided with three major food security meetings and summits: London food summit held on 23 April 2008 in the UK, Food summit held 3-5 June 2008 in Rome and G8 summit held on 8 July 2008 in Japan. The news coverage by the China Daily largely shows a similar pattern, with higher numbers 
of coverage from April to July 2008 (Figure 2). This pattern of media coverage is similar to that of media coverage of previous humanitarian crises such as the 1998 famine crisis in the Horn of Africa and in Sudan. ${ }^{49}$ In all cases intensified news coverage were only sustained for a brief period of time.

Figure 1 Number of news stories (Major World Newspapers group)

Figure 2 Number of news stories (China Daily)

In terms of the main event frame, ${ }^{50}$ while $18.3 \%$ of the news stories adopted multiple event frames, $12.9 \%$ of the news stories from 'Major World Newspapers' group solely defined the food crisis as a 'security' issue, following $19.1 \%$ and $16.1 \%$ of the news stories identifying the crisis as a humanitarian issue and economic issue respectively (see Table 1). Stories adopting security frame typically discussed food riots and unrests which led to local political instability (e.g. ousting of Haiti's Prime Minister) and threat to democracy. Others more explicitly discussed food riots that purportedly resulted in population movements across national borders, creating possible regional conflicts and disorders.

Table 1 Main event frame (Major World Newspapers group)

In contrast to the short-lived attention of the media (Figure 1 and 2), the food price spike is described in many stories as a long-term condition, with special emphasis on population growth by 2050: 
A farmer John Sexton said that with the planet's population expected to grow from 6.5 billion to 8.9 billion by 2050, "just how we are going to survive, I'm not sure". - New Zealand Herald (26 April 2008)

So why is the world running short of food? And what, if anything, can be done? The basic cause is good old-fashioned supply and demand. The world's population stands at 6.7 billion, and is set to rise to nearly nine billion by 2050. That means we have to feed the equivalent of another two Chinas. As China and India have got richer, demand has also spiralled. Sunday Mail (Australia) (27 April 2008)

The above framing of the problem suggests that the world food shortage is a long-term problem, alluding to UN estimates of major population increase. Making reference to 'planet's/ world's population', these news stories indicate the wide scale of the food price spike, both spatially in its current extent and temporally in its expected trajectory. Drawing on speculations and their implications for security, the framing of the 'problem' is underpinned by neo-Malthusian fear - a world that already (or will soon) have too many people and not enough food to go around - and the public's geopolitical imaginations of a 'small planet', reflecting geopolitical framings identified by Somerville et al that promulgate a neo-Malthusian and securitized reading of food security in policy narratives. ${ }^{51}$ 
After providing a context for the global crisis as a worrying long term condition, many news stories provided causal analysis of the crisis, usually following the fact/s of food shortage introduced. ${ }^{52}$ Content analysis of the culprit frame shows that sub-frames of 'biofuel' ( $\mathrm{n}=176 / \mathrm{p}=11.8 \%)$ and '(food demand from) China and India' ( $\mathrm{n}=114 / \mathrm{p}=7.7 \%)$ are the most blamed 'culprits', ${ }^{53}$ followed by 'rising oil price' and 'adverse weather conditions' (see Table 2).

Table 2 Most and least blamed culprits of food price spike (Major World Newspapers group)

Overall 114 news stories specifically identified 'China and India' as representatives of the 'rising population' as a main culprit in the food crisis. ${ }^{54}$ The cause of China and India for food crisis often appears in the headlines, a representation which makes them look more 'primary' than other culprits:

‘China's new appetites likely to spawn global politics of scarcity’ International Herald Tribune (US) (1 April 2008)

'Climate change, China's increasing consumption and the dash for biofuels are causing food shortages and rocketing prices' - Observer (UK) (13 April 2008)

'Bush blaming Indians for food shortage takes the cake' - New Straits Times (Malaysia) (12 May 2008)

The discussion of China and India is often presented as the explanation for various facts and statistics of food shortage, and this structure is particularly evident in shorter stories. 
For example, the story carried by the Toronto Star (based on Reuters News Agency material) ${ }^{55}$ on 24 April 2008 identifies several factors for food price spike, following the alarming message of food shortage constructed around the key information of 'food ration':

Headline: Sam's Club rationing rice; Many stores in the U.S. are limiting bulk sales of some kinds of the grain as supply fears leap

Text: In another sign the global food crisis is hitting North American consumers, Wal-Mart Stores Inc. says it is limiting sales of some kinds of rice at many Sam's Club warehouse-style stores in the United States due to "recent supply and demand trends”...The cost of basic grains, such as wheat, corn and soybeans, has been soaring due to demand in fast-growing economies, such as China and India, rising fuel and fertilizer prices, competition from biofuels and market speculation.

It is interesting to see how the culprit frame - China and India - is embedded in the discursive construction by the Toronto Star. The key information of the news agency material has been used as a lead for a 'bigger' story: The ration imposed on rice is subsequently linked to the message of food shortage, followed logically by the 'cause' of the food shortage and soaring price. The rather neutral piece of information about ration on rise supplied by Reuters has now generated more political content - global food insecurity resulting from China and India’s bigger demand, rising fuel and fertilizer prices, competition from biofuels and market speculation. In this story several culprits of 
the food crisis are identified, but the fact that 'China and India' are listed first - a discursive practice called foregrounding - gives a stronger impression to the readers that they are the most important factor.

The blame on China and India represented by the media is different from the reports from authoritative organizations such as the FAO (2009) and DEFRA (2010). ${ }^{56}$ According to these reports, factors contributing to the food price spike include demand side (biofuel, US dollar devaluation, aggressive purchase and increasing demand for food) and supply side (weather, oil price, protectionist export policy, slow growth in agriculture production, rising farm production cost). In particular, these two reports comment on role of China and India as follows:

However, the high commodity prices of 2007 and 2008 do not seem to have originated in these emerging markets. Cereal use in China and India has in fact been growing more slowly than in the rest of the world... China and India have not been the cause of the sudden price spikes in the oils complex, but this does not downplay their role nor that of changing consumption patterns in general on developments in food markets both in the past and in the future. (The State of Agriculture Commodity Markets, FAO 2009: 12)

As the structure of the world economy changes, and countries such as India and China see incomes grow, it is to be expected that they will have an impact on international prices. However, the growth of Chinese and Indian 
consumption of grains and meat over the last ten years has actually been relatively modest. (The 2007/08 Agricultural Price Spikes: Causes and Policy Implications, DEFRA 2010: 12)

The 'modest' factor - rising demand for food from China and India - has received disproportionate amount of blame for the food crisis. Although news articles rarely assign blame to a primary culprit, $10 \%$ of them did. Within the Primary Culprit category again 'biofuel' and 'China and India' received highest percentages of blames. ${ }^{57}$ Following that, ‘climate change’, 'rising population', 'rising oil price’ and 'adverse weather conditions' received relatively high percentages of blames. It is interesting to note that 'adverse weather conditions' and 'climate change' are usually discussed as two separated factors that have no connection. On the other hand, culprits receiving the lowest percentages of blames include ‘anti-GM', 'US dollar devaluation', ‘agricultural liberalization', and ‘food aid system'. Unequal agro-distribution system $(n=8 / p=0.5)$ and global food empire $(\mathrm{n}=5 / \mathrm{p}=0.3 \%$ ) also received few blames. These 'promoted' and 'relegated' factors identified here show that the media provided little challenge to the existing discourse of food security privileging securitization of resources but ignored the structural inequalities in the global food system dominated by agro-liberalization and transnational food corporations.

The blame on China and India by the media, as concluded by previous research, ${ }^{58}$ is partly resulted from inaccurate and confusing statistics and figures available for journalists. But it is also because of the ideological positions of the media organizations 
(and their wider socio-cultural context) that view China and India as a threat. The stateowned China Daily which represents the official voice of the Chinese government rejected the accusation, and identified three main factors of the food crisis as 'biofuel', 'rising oil price' and 'agricultural subsidies in developed countries' (see Table 3). Not surprisingly the culprit 'China and India' and their demand for food received fewer blames in the China Daily. Additionally the China Daily printed a series of articles arguing that China is a positive and crucial factor, rather than a threat, to world food security. One of the stories ('Why China is crucial to world food security'15 May 2008) was based on an address of Anthea Webb, the WFP China director. Another article ('Don’t blame us for food crisis' 5 June 2008) quoting the former Minister of Agriculture of China Sun Zhengcai at the Rome World Food Security summit, again defended China's role in 'contributing greatly to world food security by providing for nearly a quarter of the world's population'.

Table 3 Most blamed culprits of food price spike (China Daily)

While the role of China in maintaining world food security is emphasized by the China Daily, a narrative built around unequal power relations between the West and East, North and South is used to construct a discourse of blame on biofuel. In an article titled 'North's biofuel appetite causing South’s starvation’ (8 November 2007), first generation cornbased biofuel was blamed for causing food shortage. Using text mainly from the Guardian (UK), the China Daily introduced the story with a cartoon below (Figure 3): The narrative of food vs. fuel constructed by the China Daily is also present in many news stories collected from World Major Newspaper group. ${ }^{59}$ Some stories constructed 
the narrative using the 'fuel tank' and 'empty stomach' contrast ('to fill the tank of one SUV with ethanol would require grain to feed one person for a year'), echoing what Robert Zoellick, the former World Bank president said 'While many are worrying about filling their gas tanks, many others around the world are struggling to fill their stomachs, and it is getting more and more difficult every day'. ${ }^{60}$ The China Daily stories relied heavily ( $\mathrm{n}=22 / \mathrm{p}=56.4)$ on news agencies and other publications including Western newspapers for its content, but it seemed that during the editorial process, culprits suiting the Chinese perspective (blaming biofuel) were cherry-picked while other damaging culprits (China and India's demand for food) were downplayed.

Figure 3 China Daily 8 November 2007

In another article 'China not to blame for food price rise' (14 June 2008) carried by the China Daily, a cartoon (Figure 4) was included to accompany texts revealing that 'Chinese meat consumption is still 45 per cent less than the average consumption in the US'. The article went on to identify US biofuel as the main problem of rising food prices. The cartoon was used to contrast the obese West (symbolized by cutleries and attire) and underfed 'others' (symbolized by animal characters with different body sizes). The blame on Western supremacy was evident, highlighting the hegemonic power of the West in deciding world's food distribution and consumption.

Figure 4 China Daily 14 June 2008 
The victims of the 2007-08 food crisis were largely identified by newspapers from the Major World Newspapers' group as 'the poor in underdeveloped countries' ( $n=283 / p=19 \%)$ and 'world poor' $(n=163 / p=11 \%),{ }^{61}$ followed by 'consumers in developed countries' $(n=57 / p=3.8 \%)$ and 'farmers' $(n=28 / p=1.9 \%)$. The relatively big number of consumer victims identified in the news media, particularly those from developed world, shows the 2007-08 food crisis affected not only the Global South, but also the Global North. The recognition of this fact by the news media challenges the geographical assumption of food security which sees 'hunger' largely existing in the Global South. The food insecure in Europe and Africa covered by several news stories transcend the North-South binary. In the meantime, this also reflects increasingly heightened anxieties about food insecurity experienced by developed countries more generally which may in turn reinforce securitized narratives building around newly emerged (middle class) consumer anxieties.

In some stories, both the Global North and South countries are facing security threat induced by food price rise:

India, Yemen, Mexico, Burkina Faso and several other countries have had, or been close to, food riots in the last year... Italians organized a one-day boycott of pasta in protest at rising prices. German leftwing politicians have called for an increase in welfare benefits so that people can cope with price rises. - Guardian (UK) (3 November 2007) 
The whole world has been affected by rising food prices. The Japanese are complaining that instant noodles are becoming more and more expensive. In September, there was a "spaghetti protest" against the rising prices of pasta in Italy...There were food protests in Mexico in February. More than 75,000 people took to the streets, slamming the government for failing to bring down the price of tortilla... A few months ago, three people were killed in a stampede at a supermarket in Chongqing, China...--South China Morning Post (Hong Kong) (10 December 2007)

Italians have protested against the price of pasta, and Mexicans against the soaring cost of corn tortillas, while food riots have struck scores of countries across Africa, Asia and the Caribbean. - Dominion Post (New Zealand) (5 June 2008)

In some stories, the 'victims' (consumers in developed countries) are juxtaposed with the ‘villains/culprits’ (China and India).

Italy is feeling the effects of booming world food prices, blamed partly on China and India, whose populations have developed Western tastes as their economies grow. Other factors include desertification, flooding and a shift in crop use from food to biofuels. - Times (6 May 2008) 
The stories highlight consumers in developed countries such as Italy and North America (rice ration story discussed earlier by the Toronto Star) as the victims of the food price rise, caused partly by food demand from China and India. Although the last excerpt from the Times has delimited the scope of the 'culprit' by using the word 'partly', it still lists China and India first as the cause of the crisis, emphasizing their Westernized taste. Other factors such as desertification, flooding and biofuel, though briefly mentioned, are not given as much space for discussion as the factor of China and India. The exclusion of detailed explanation of other factors and the random arrangement of the order of the factors (China and India were listed first) again 'foregrounded' the role of China and India in the food crisis.

The juxtaposition of 'villain' and 'victim' is made more explicit when some stories describe China's operation in Africa. In particular, the media draw on moral and emotional involvements of the readers by highlighting a binary opposition between the Global North and Global South regarding food security. In these constructions, China is singled out from India and constructed as an even bigger villain together with other investors for their aggressive and vicious 'land grabbing' practice in Africa, which allegedly resulted in more severe food insecurity for landless local people.

Some food importers, including China, South Korea and the United Arab Emirates, are even considering locking up fertile land in other countries to grow their food. - Washington Times (US) 15 May 2008 
Headline: China looks abroad to grow its own food

Text: CHINESE farming companies may be backed by the government to buy and lease tracts of land in Africa and Latin America to grow crops to feed its 1.3 billion people. - Daily Telegraph (UK) (10 May 2008)

In the last 20 years, China's economic growth has created dependency on energy source, raw materials, natural resources, and this has motivated China to exploit resources globally due to its lack of sufficient indigenous energy, causing geopolitical concerns ground the globe ${ }^{62}$ China's development practices have spawned much fear for China's threat to the existing 'order' in Africa ${ }^{63}$ Moreover, China has provided an alternative growth model based authoritarian capitalism that does not share democratic values and universal rights with the West. ${ }^{64}$ The negative externalities generated by China's growth such as environmental implications and China's lack of interest in 'managing these externalities' in the past have put it under an unfavorable spotlight. ${ }^{65}$ Within this broader context, the media discourse of 'China's land grab' tend to represent China as a strange, immoral, and greedy 'villain' that secures its food re/sources at the expense of the undernourished people in Africa. ${ }^{66}$ However, the media representation of China as a 'strange, immoral, and greedy' villain is simplified and stereotyped construction. Although there is some truth to the claims based on which the 'fear' for China is formed, especially in relation to China's rising demand for food and its implications for global food prices, ${ }^{67}$ it is important to differentiate the Chinese urban middle class (and their food demand) from the under-nourished rural poor whose food security is yet to be achieved. Moreover, many publications maintain that despite such higher demand for 
food, China is self-sufficient in most major grains, ${ }^{68}$ and that China's entrance into the world market can increase profits and trade in Africa. ${ }^{69}$

Despite some recent sympathetic and favorable view of China's African expansion, ${ }^{70}$ the discourse of 'China as a strange emerging super-power' still dominates much of the discussions in the international community, especially in the US foreign policy. ${ }^{71}$ Overall the media construction of China as the 'villain' who inflicts pain on the 'victims' (consumers in the Global North and the poor in Africa) to a large extent reflects the 'us'/'them' and 'inside'/'outside' attitudes inherited from the cold war mentality and revitalized from recent anxieties about China's rise. And assigning blame to 'them' 'works further to strengthen the territorialization of concern, focusing attention on their problem (in this case China's rise) in the context of how they affect us ${ }^{72}$ Moreover, the 'us'/'them' attitude is problematic as much of the 2007-08 food crisis was induced by the interconnected financial market (US dollar depreciation) and interconnected global food system (demand for biofuel at the international market). ${ }^{73}$ Territorializing this problem as a 'Chinese and Indian' problem constructs a geopolitical narrative which tries to separate a cause from other interconnected causes of the 2007-08 global food crisis. The consequence of this construction based on the discourse of separation and securitization is to marginalize other approaches towards global food insecurity based on international 'collaboration' ${ }^{74}$

\section{Framing and Media Source Relationship}


After analyzing the media construction of the narratives of the 2007-08 global food crisis, in particular the blame frame constructed around China and India, we now turn to the sources of media to examine how they also shape the re(production) and circulation of geopolitical discourses. As demonstrated previously in Figure 1, the coverage of the food price spike concentrated between April 2008 and June 2008. The 'dense' media coverage seemed to have followed a series of high-profile announcements, forums and meetings of international organizations and aid agencies. For example, the high-profile Rome Food Summit held 3-5 June 2008 generated 28 news stories between 28 May and 19 June 2008, all of which cited the summit extensively. Political catchphrases also seem to have generated news coverage, as with the 'silent tsunami' expression used by (then) World Food Program director Josette Sheeran to describe the food crisis:

Last week Josette Sheeran, head of the World Food Program, described the crisis as a "silent tsunami" and called for an international response on a similar scale to that to the Boxing Day tsunami, which killed more than 250,000 people and destroyed many more homes and livelihoods. - New Zealand Herald (26 April 2008)

The term 'tsunami' is itself evocative of Asia, due both to its Japanese etymology and to recent major occurrences, and may have unintendedly contributed to geographically lay blame onto Asia. ${ }^{75}$ When Josette Sheeran commented on the food crisis 'a silent tsunami of hunger is sweeping the world's most desperate nations' in a London food summit 23 April 2008, this alarming yet catchy comment appeared in 17 stories (sometimes in 
headlines) by the end of May 2008. ${ }^{76}$ Other newspapers such as the Washington Post ('Food Crisis is Depicted As "Silent Tsunami”' 23 April 2008) largely reproduced Sheeran's speech based on the materials from the Associated Press news agency. It seems that Sheeran's comment at the high-profile summit was a key piece of information for many news agencies whose wire service was then used by their media clients. In early March 2008, Sir John Beddington, a professor of biological and the former UK Government chief scientific adviser started using 'perfect storm' to describe the global food shortage. In April 2008, Sheeran also used 'perfect storm' to describe factors contributing the food crisis, and this term was subsequently re-used by Jeffrey Sachs, an economist at Columbia University and a special adviser to the UN secretary Ban KiMoon. ${ }^{77}$ The term also made appearance in Ban's article 'The new face of global hunger' which was published by The Washington Post on 12 March 2008. Altogether from beginning of March to 8 June 2008, 'perfect storm' appeared in 17 news articles. Another comment 'new face of hunger' which was shared by the UN officials including Sheeran and Ban appeared in another 8 news stories from the beginning of April to the end of May 2008. In April 2008, the former UN Undersecretary-General for Humanitarian Affairs John Holmes, officially called the food price spike as 'global food-price crisis' and commented that the crisis was caused by 'changing dietary patterns, prosperity in countries like China and India, [diverting crops for] fuel and lower [food] reserves' ${ }^{78}$

It is unsurprising that these high-profile events, experts and leaders have drawn a lot of attention from journalists. This supports a trend in political and public communication that news sources tend to be dominated by powerful actors such as governments, 
corporate, political parties and organizations that control resources in money and public relations expertise. ${ }^{79}$ In part, the frequent occurrence of the high-profile events and announcement in April, May and June 2008 explains the dense media coverage during the same period. When the events subsided, so did the news coverage. The catchphrases ('silent tsunami' and 'perfect storm') may have also encouraged media coverage as the images and consequences associated with these phrases create 'catchy' headlines. Not only the media use eye-catching phrase to create headlines with the aim of boosting sales, but experts, scientists and world leaders themselves seem to resort to language tactics to promote their own agendas (and notoriety). On the biography page of the former UK Government Office chief scientific advisor Sir John Beddington, ${ }^{80}$ his contribution to bring the concept of "perfect storm' onto the media and political agendas is commented on as follows:

Throughout 2008 and 2009 Sir John raised the concept of the "Perfect Storm" of food, energy and water security in the context of climate change, gaining considerable media attention and raising this as a priority in the UK and internationally.

In the information age in which readers encounter a plethora of media messages on a daily basis, interests groups and stakeholders have become increasingly adept at packaging information to obtain media attention. Advanced public relations and public communication techniques for packaging information are no longer only employed by governments, corporations and ideologically-driven 'think-tanks', but also by the UN 
agencies, powerful NGOs, universities, individual scientists and experts. ${ }^{81}$ Such techniques are particularly important in the post-2008 financial crisis context in which policy-makers and members of the civil society supporting austerity measures, bank bailouts and foreign aids all compete for the same pool of public resources. It is therefore important for the 'world food security' policy community to maintain media attention in the public sphere.

Content analysis of the 'solver' frame found the sub-frames of 'international agencies', 'governments' and 'individual countries' are the most frequently mentioned, which indicates that mainstream institutions of food security are also predominantly represented in the media (see Table 4). On the other hand, sub-frames such as 'urban communities', 'food firms', and 'charities and NGOs' related to alternative approaches such as food justice and sovereignty are far less visible in the 'solver' frame. It is interesting to note that 'farmers (large industrial farming)' which has been criticized for its environmental implications (e.g. endangering biodiversity and fuel-dependent) is one of the least mentioned solvers.

Table 4 Most and least mentioned solvers of food price spike (Major World Newspapers group)

Related to the 'solver' frame is the 'solution' frame which again champions the most dominant neoliberal solutions to food insecurity 'food donation and aid' ( $\mathrm{n}=87 / \mathrm{p}=23.4 \%$ ), followed by 'free trade and market' ( $n=26 / p=7 \%)$ and 'increase agricultural production (general)' ( $n=22 / p=5.9 \%)$. Interestingly, the three top solutions identified by the China Daily - 'stop biofuel' ( $\mathrm{n}=5 / \mathrm{p}=12.8 \%)$, 'food donation and aid' $(\mathrm{n}=5 / \mathrm{p}=12.8 \%)$ and 'free 
trade and market' ( $\mathrm{n}=5 / \mathrm{p}=12.8 \%)$ - shared part of the solutions identified by the Major World Newspapers group. The least mentioned solutions by the Major World Newspaper group include 'curb big agro-business' ( $\mathrm{n}=1 / \mathrm{p}=0.3 \%$ ), 'large (industrial scale) farming' $(\mathrm{n}=1 / \mathrm{p}=0.3 \%)$, 'regulate market speculation' $(\mathrm{n}=2 / \mathrm{p}=0.5 \%)$ and 'change consumption' $(n=2 / p=0.5 \%)$. While the ' $N / A$ ' sub-frame $(n=60 / p=16.1 \%)$ shows that a significant number of news stories did not prescribe a primary solution, around $14 \%$ of the news stories identified multiple solutions ('Other' $\mathrm{n}=52 / \mathrm{p}=14.2 \%$ ). Among the 52 news stories that stated that multiple solutions were needed, 25 of them followed the task force paper presented at the Rome summit 3-5 June 2008 that identified short, medium and long term solutions including food aids, farm production assists (seeds and fertilizer) to poor farmers, freer flow of trade and agricultural R\&D. (Figure 5)

Figure 5 Distribution of most mentioned solutions (number of stories) (Major World Newspapers group)

The above analysis shows that drawing on key sources such as the UN officials (e.g. Josette Sheeran) and highlighting dire consequences ('silent tsunami’), news media have successfully transformed the food crisis into a high-priority spectacle that commands immediate political/policy attention in the mid of 2008. In the meantime, the media have also transmitted the dominant frames from the key sources to the public domain. Sir John Holmes' comment on the role of China and India as a factor for global food price rise was one piece of such information passed from the source to the media and circulated among them. ${ }^{82}$ The elite-based news sources (e.g. political leaders, chief scientists, leaders of international organizations) are likely to pre-define the narrative structure of the food crisis, and therefore limit the ability of journalists' to carry out independent and 
critical analysis of the complex issue. As Gamson and Modigliani have argued that news frames are influenced by source selection as the source often becomes the story's 'organizing principle'. ${ }^{83}$ Relying on quotes, definitions and interpretations from the UN agency officials and government advisors, media analysis of food security is inevitably shaped by the conceptions and ideas of the dominant actors. Table 5 below reveals that the main sources of the new stories are mostly global food governance institutions including governments and inter-governmental organizations. While many news stories quoted charities and NGOs such as Oxfam and Friends of the earth mostly at the end of the story to give the new coverage a feel of balance and objectivity, key sources of information usually came from the mainstream institutions and was usually discussed as the beginning of the story.

Table 5 Source of information (Major World Newspapers group)

It is worth noting that during the Rome Food Summit, 'biofuel', the number one 'culprit' of the 2007-08 food crisis, was extensively debated by advocates represented by the US president Bush and Brazilian president da Silva and opponents represented by leaders from developing countries, leading many newspapers to conclude that 'politics overshadows aids' (the International Herald Tribune, 5 June 2008), and that the Summit 'struggle for a deal on food crisis' (the Irish Times and the Advertiser [Australia] 5-6 June 2008). Despite different views, the news media have offered a platform for perspectives regarding the roles of biofuel, in particular second generation biofuel in relation to agriculture, food security and climate change. Another main culprit of the food crisis, 'China and India' (and their demand for food) has only been quoted very few times 
throughout time period analyzed in this study by the 'Major World Newspapers' group. Delegates from Chinese government criticizing biofuel policies at the Rome Food Summit were quoted only once by the International Herald Tribune on 5 June 2008. Former US president Bush’s comments on India's middle class driving food prices up, was covered a couple of times. ${ }^{84}$ The New Straits Times (Malaysia 12 May 2008) story 'Bush blaming Indians for food shortage takes the cake') quoted an India politician Brinda Karat called Bush’s comment a 'reflection of an imperialist mentality'. Overall, there seems very limited exchange of perspectives regarding food security between the East and West. It also shows that the news media as part of the civil society have not made much effort to facilitate exchange of views and perspectives regarding food security in the global public sphere, or act as an active force seeking for collaboration to solve the interconnected global food crisis. The news media's focus on blames, rather than engagement, further contributes to the 'us/them' binary that may reinforce securitized narratives of food security.

Textual analysis of news articles also shows that media coverage of the food crisis is becoming increasingly similar regarding key facts, information and sources. This can be partly explained by the fact that news institutions are heavily relying on news wire service for international news reporting due to competitive and speed-oriented media market. ${ }^{85}$ This research found $12.1 \%$ of the news articles acknowledged using materials from news agency (texts and images). 9.9\% of the articles acknowledged using content from other publications (other newspapers or magazines). ${ }^{86}$ Additionally $2.7 \%$ of the news stories were based on recycled materials published before. Newspapers within the 
same newspaper syndicate often share news stories, and they print identical content with (sometimes) different titles. ${ }^{87}$ Previous research in journalism studies shows that copy/paste practices are common not only between news agencies and their clients (mostly clients copying news agencies' materials), but also among rivalry news agencies. ${ }^{88}$ Practices like this in news gathering and reporting result from changes in the media environment including digitalization (and therefore unlimited space for news) and market competition. Changes like this have led to increasing use of convenient, cheap, un-checked and second-hand materials. ${ }^{89}$ The lack of fact-checking and sourceinterrogating undermines the accuracy and quality of journalism, and the role of media in shaping public understanding, debates and political pressure. Such changes in journalism should also be taken into consideration when analyzing the construction of geopolitical narratives of food security in the global public sphere. As demonstrated above, to a large extent the narrative regarding the solver of and solution to food security dominated by aid agencies, international organization and national governments entered into the mass media through the channel of news sources. When news agencies and their media clients uncritically recycle their stories mainly based on comments, activities, and framing of the 'hegemonic institutions' of food security, they contribute to speeding up the circulation of these dominant interpretations and narratives in popular culture.

Another possible explanation for such simplistic, reductionist and uncritical journalistic work in relation to 2007-08 food crisis is related to the nature of the crisis. Unlike previous humanitarian crises such as Rwanda and Bosnia which were limited to certain geographical locations, the food crisis related events were distributed across the world. It 
posed a challenge for journalists, and foreign correspondents particularly, to be physically present and develop their compassion, moral responsibilities and more importantly 'attachment' and 'obligation' to engage with the crisis, with an aim of resisting and critiquing dominant geopolitical practices based on 'a global agro-industrial model' ${ }^{90}$

\section{Conclusion}

This paper examined the ways in which news media engaged with and contributed to geopolitical representations of the 2007-8 'food crisis' and global food security. This analysis focused on narratives of victimization and culpability, as well as causal explanation and problem solving. In addition to framings of the food crisis as an 'humanitarian' or 'economic' issue, a large number of news stories ( $\mathrm{n}=48 / \mathrm{p}=12.9 \%)$ solely defined the food crisis as a 'security' issue with potentially dire implications for political stability around the world. While a variety of inter-connected 'crisis factors' are generally identified, many news media over-emphasized the 'Asia threat', with China and India being represented as the second most primary culprit of the crisis following biofuel. This is in contradiction with the 'modest' impact of food demand from China and India on global food markets, as reported by FAO and UK DEFRA. China's framing, in particular, rested on association with various 'facts' of global food shortage, such as rice rationing in specific US shops, a juxtaposition of Chinese consumers with 'their victims' in both the Global North and Global South, thus implicitly representing China, and more 
generally 'rising Asia', as the new 'immoral global villains'. Such simplified and stereotyped representation by some media partly reflects broader geopolitical discourses in the West (especially the US) through which China's rise on the world stage is cast as a threat, and particularly so for Africa, itself the object of victimization narratives. Through such antagonizing blame, media representations risk potentially excluding and marginalizing alternative approaches to food security based on greater international collaboration, and further feed geopolitical fears and securitization policies against China. Both the news media from the Major World Newspapers group and Chinese state media have made little effort to facilitate exchange of views and perspectives regarding food security or engaged with each other via open and constructive dialogue. Both assigned blame instead of engaging in discussions of alternative solutions to food security, such as revisiting dietary patterns and meat consumption in both China and the West. ${ }^{91}$

The food price spike is largely framed through a top-down institutional approach and prism; with much media coverage (including news wires) prompted by high-profile announcements, forums and meetings of governments, international organizations and aid agencies. . In turn, media narratives predominantly identify these organizations as the solvers of food price spike. Unsurprisingly, solutions to food insecurity identified by the news media (including the China Daily) - 'food donation and aid', 'free trade and market' and 'increase agricultural production' - mostly reiterated hegemonic food security policies based on neoliberal and geopolitical concerns, rather than approaches suggested by alternative food security movements and farming communities in the most affected regions. $^{92}$ 
The mainstream media coverage thus shows, unsurprisingly, a rather limited role in challenging dominant geopolitical framings of the food crisis emphasizing securitization and neoliberal development. In the meantime, the news media have demonstrated little power in including alter-geopolitical political viewpoints and issues that are not expressed within the mainstream political establishment, performing what Bennett named as 'indexing' practice. ${ }^{93}$ The heavy reliance of the media on powerful institutional sources (e.g. the UN) in covering the 2007-08 food crisis needs to be understood within a broader context of changing news gathering and reporting practices including the increasing use of convenient, cheap, un-checked and second-hand materials. Such practices give unchecked access of the elite-based sources to the public domain, helping them pre-define, reproduce and circulate the dominant neoliberal geopolitical narratives of the food crisis promoted by mainstream food security institutions in the public sphere.

To explain the passive role of the media, one should consider the particular nature of the food crisis that makes the news media susceptible to political power and vulnerable to 'simplistic' journalism. The 2007-08 food crisis was essentially foreign news to most of the newspapers analyzed in this study based. Over the years, a range of problems of foreign news reporting have been identified, ranging from ideological perspective to structural and organizational issues of the news institute (e.g. the decline number of foreign correspondents and bureaus), all of which have potential impact on the overall quality of foreign news coverage. Reductionist and simplistic views of, or even worse inaccurate information on foreign issues often enter into public domain and therefore 
shape public perceptions via journalistic work. ${ }^{94}$ The domination of foreign news production by news agencies and big media organizations inevitably exacerbates the situation. ${ }^{95}$ Additionally the worldwide distribution of food crisis related events (and causes) poses a challenge for news media (journalists in particular) to become personally 'attached' and morally committed to the crisis and to seek for alternative geopolitical narratives. ${ }^{96}$ To facilitate 'a counter-geopolitics of food security for re-situating agrofood politics outside hegemonic policies and institutions' suggested by Somerville et al is even more challenging for the news media, as mainstream food security institutions (including the Chinese government) operate in a high policy certainty environment regarding the solutions to food crisis, and dominate sources of media framing. ${ }^{97}$ According to Robinson's media-policy interaction model, in the absence of mainstream policy uncertainty creating gaps for media to magnify critical alternative voices, the media are unlikely to resist the dominant neoliberal geopolitical framing of food security in the public domain. ${ }^{98}$

The findings presented here have provided some preliminary analysis of the ways in which news media engage with the geographical complexities of the global food security. The paper makes no claim to include all representations of geopolitical narratives of food security in the news media. It only highlighted a number of key narratives about how rising demand for food from China and India, in particular China, is represented as a global threat; and how a competing narrative constructed by the Chinese official newspaper emphasizes China's contribution to world food security, but also adheres to mainstream neoliberal solutions to food security. Other competing discourses represented 
by India and Brazil based media from the Global South may better demonstrate the diversity within Global South, and problematize Global North/South geographical assumption in relation to food security. Grassroots and alternative movements (e.g. Food Sovereignty) supporting more sustainable food production and consumption are increasingly gaining popularity in both the Internet and traditional media and are therefore worth studying. Tabloid newspapers may frame the food crisis differently based on their ideological framework and human-interest news angles. Future research is required from an audience perspective ${ }^{99}$ and media-source study such as public relations materials from agro-industries to provide a more conclusive answer to the whole 'circuit' of producing, distribution and consumption of geopolitical narratives about food security.

The author would like to thank three anonymous reviewers and editors for comments and suggestions on previous drafts of this article.

\footnotetext{
Notes

${ }^{1}$ D. Johnson, 'Introduction to a Symposium on the 2007-08 World Food Crisis' Journal of Agrarian Change, 10/1(2010) pp. 69.

2 Food and Agriculture Organization (FAO) 'The State of Food Insecurity in the World 2008', available from: ftp://ftp.fao.org/docrep/fao/011/i0291e/i0291e00.pdf, p. 4 accessed 23 September 2011.

${ }^{3}$ A. Faiola, 'A brutal convergence of events has hit an unprepared global market, and grain prices are sky high. The world's poor suffer most', the Washington Post (27 April 2008), available at http://tria.fcampalans.cat/images//Washington\%20Post_aliments.pdf, accessed 16 June 2013.

${ }^{4}$ Food and Agriculture Organization (FAO) 'The State of Food Insecurity in the World 2010', available from: http://www.fao.org/docrep/013/i1683e/i1683e.pdf>, accessed 23 September 2011; P. Rosset, 'Agrofuels, Food Sovereignty, and the Contemporary Food Crisis' Bulletin of Science, Technology \& Society 29/3 (2009) pp. 189-193; D. Heady, and S. Fan, 'Anatomy of a crisis: the
} 
causes and consequences of surging food prices', Agricultural Economics, 39 (2008) pp.375-391; E. Dowler, M. Kneafsey, H. Lambie, A. Inman, and R. Collier, R. "Thinking about 'food security': engaging with UK consumers” Critical Public Health, 21/4 (2011) pp. 403-416; John Ingram, Polly Ericksen and Diana Liverman, Food Security and Global Environmental Change (London and Washington, D. C: Earthscan 2010); Department of Environment, Food and Rural Affairs (DEFRA) 'The 2007/08 Agricultural Price Spikes: Causes and Policy Implications (2010)', available from <http://archive.defra.gov.uk/foodfarm/food/pdf/ag-price100105.pdf>, accessed 4 February 2010; L. R. Brown ‘The New Geopolitics of Food’ Foreign Policy Available from

$<$ http://www.foreignpolicy.com/articles/2011/04/25/the_new_geopolitics_of_food?page=0,3>, accessed 02 July 2012; USDA Economic Research Service, 'Global Agricultural Supply and Demand: Factors Contributing to the Recent Increase in Food Commodity Prices', available from http://www.ers.usda.gov/publications/wrs-international-agriculture-and-trade-outlook/wrs0801.aspx, accessed 5 March 2011; The Guardian 'Global food crisis series: More wealth, more meat. How China's rise spells trouble’ available from http://www.guardian.co.uk/environment/2008/may/30/food.china1, accessed 22 November 2009. ${ }^{5}$ J. D. van der Ploeg, 'The Food Crisis, Industrialized Farming and the Imperial Regime', Journal of Agrarian Change, 10/1(2010), pp98; T. Lang, 'Crisis? What Crisis? The Normality of the Current Food Crisis' Journal of Agrarian Change, 10/1(2010), pp.87-97; J. Ghosh 'The Unnatural Coupling: Food and Global Finance' Journal of Agrarian Change, 10/1(2010) pp.7286; M. Somerville, J. Essex and P. Le Billon, 'The "Global Food Crisis" and the Geopolitics of Food Security', Geopolitics, forthcoming (issue number and page number to be supplied pending publication)

${ }^{6}$ D. Johnson, 'Introduction to a Symposium on the 2007-08 World Food Crisis' Journal of Agrarian Change, 10/1(2010) pp. 71.

${ }^{7}$ See Somerville et al (note 5)

${ }^{8}$ Ibid.

${ }^{9}$ Dowler et al (note 4) pp. 404; T. O’Brian, ‘Food Riots as representations of insecurity: examining the relationship between contentious politics and human security' Conflict, Security \& Development, 12/1 (2012), p.38.

${ }^{10}$ Statistic from the USAID quoted by Dustin Mulvaney, Green Food: An A-to-Z Guide (Thousand Oaks, London: Sage: 2010) pp. 200. Also see Dowler et al (note 4) pp. 405; R. Huish, 'Human Security and Food Security in Geographical Study: Pragmatic Concepts of Elusive Theory?’ Geography Compass 2/5 (2008) pp. 1392. This conception which ignores food insecurity among the poor in industrialised nations, is being addressed by many policy initiatives and grassroots local food movements in recent years, for example the Healthy Start programme and Foresight projects in the UK and Slow Food movement.

${ }^{11}$ See J. Essex, 'Sustainability, Food Security, and Development Aid after the Food Crisis: Assessing Aid Strategies across Donor Contexts', Sustainability, 2/11 (2010) pp.3362; J. Essex, 'Idle Hands Are The Devil's Tools: The Geopolitics and Geoeconomics of Hunger', Annals of the Association of American Geographers, 102/1 (2012) pp.192. The use of such geographical divides - such as north/south - (re)produce assumptions and prejudices, while obscuring diversities within these entities and the complexities of the 2007-08 food crisis.

${ }^{12}$ See J.E. Kodras, 'Shifting Global Strategies of US Foreign Food Aid, 1955-1990', Political Geography 12/3 (1993) pp 232-246; for a qualification in the 1990s, see E. Neumayer, 'Is the Allocation of Food Aid Free from Donor Interest Bias?', Journal of Development Studies 41/3 (2005), pp. 394-411. Beyond the 'Global South' and prior to the advent of the 'international development' apparatus, see for example D.S. Foglesong, America's Secret War Against Bolshevism: U.S. Intervention in the Russian Civil War, 1917-1920. UNC Press. 
${ }^{13}$ See J. Essex 2010; 2012 (note 11) and C.B. Barrett and D.G. Maxwell, Food Aid After Fifty Years. Routledge (2005).

${ }^{14}$ See A. Boland, 'Feeding fears: competing discourse of interdependency, sovereignty and China’s food security’, Political Geography 19/1 (2000) pp. 61.

${ }^{15}$ Ibid.

${ }^{16}$ See I. Hofman, and P. Ho, 'China's 'Development Outsourcing': A critical examination of Chinese global 'land grabs' discourse. The Journal of Peasant Studies, 39/1 (2012) p.1-48.

${ }^{17}$ See Somerville et al (note 5).

${ }^{18}$ See G. O'Tuathail, 'The Postmodern Geopolitical Conditions: States, Statecraft and Security at the Millennium', Annals of the Association of American Geographers 90/1 (2000) pp. 167.

${ }^{19}$ Many argue that food security is not resulted from lack of food, but unequal relations between the global North and South. Despite much criticism, the neoliberal geopolitical paradigm of food security emphasizing trades and aids is still the main one, although developments for this paradigm (e.g. improving aid delivery) are being explored. See Mulvaney (note 10) pp. 202; Huish (note 10)) pp. 1393; Young, E. M. (2004) Globalization and food security: novel questions in a novel context? Progress in Development Studies. Vol. 4(1): 1-21.

${ }^{20}$ For instance, the questions of production and access were central to the food insecure Global South in the past, but more recently the definition of food security has been broadened to the maintenance of access to nutritious, safe, sustainable, inexpensive and diverse food to 'all people, at all times' - a 'paradigm shift' motivated by health and justice concerns and food safety concerns ('food scares') in the Global North, and greater concerns for political-economic entitlement and cultural rights for the vulnerable in the Global South. The FAO defines food security as 'food security exists when all people, at all times, have physical, social and economic access to sufficient, safe and nutritious food that meets their dietary needs and food preference for an active and healthy life. See Food and Agriculture Organization of the United Nations (FAO) The State of Food Insecurity in the World 2010. Available from http://www.fao.org/docrep/013/i1683e/i1683e.pdf, accessed 23 September 2010. Also see E. Dowler et al (note 4) pp. 405; P. Ericksen 'Conceptualising food systems for global environmental change research’ Global environmental Change 18/1 (2008) pp. 234-245; See L. Jarosz, 'Defining World Hunger: Scale and Neoliberal Ideology in International Food Security Policy Discourse', Food, Culture \& Society, 14/1 (2011) pp. 135; S. Maxwell, 'Food Security: a post-modern perspective', Food Policy, 21/2 (1996) pp.163.

${ }^{21}$ See Somerville et al (note 5).

${ }^{22}$ P. McMichael \& M. Schneider, 'Food Security Politics and the Millennium Development Goals', Third World Quarterly, 32/1 (2011) pp. 119-139; also see Somerville et al (note 5).

${ }^{23}$ See G. O'Tuathail's discussion of formal and practical geopolitics ('geopolitical thought and the geopolitical tradition/the everyday practice of statecraft') and popular geopolitics ('popular culture, mass media and geographical understanding' in 'Understanding critical geopolitics: geopolitics and risk society’, Journal of Strategic Studies, 22/2-3 (1999) pp.111.

${ }^{24}$ S. Carter, 'Mobilising generosity, framing geopolitics: Narrating crisis in the homeland through diasporic media', Geoforum 38(2007) pp.1102-1112; S. Dalby, "Reading Rio, writing the world: the New York Times and the 'Earth Summit'”, Political Geography 15/6-7 (1996) pp.593-613; E. Mawdsley, 'Fu Manchu versus Dr Livingstone in the Dark Continent? Representing China, Africa and the West in British broadsheet newspapers', Political Geography $27 / 5$ (2008) pp. 509529; T. McFarlane and I. Hay, 'The battle for Seattle: protest and popular geopolitics in The Australian newspaper', Political Geography 22/2 (2003) pp. 211-232; G. Myers, T. Klak and T. Koehl, 'The inscription of difference: news coverage of the conflicts in Rwanda and Bosnia', Political Geography 15/1 (1996) pp. 21-46; G. O’Tuathail, 'The Frustration of Geopolitics and the Pleasure of War: Behind Enemy Lines and American Geopolitical Culture’, Geopolitics 10/2 
(2005) pp. 356-377; J. P. Sharp, 'Hegemony, popular culture and geopolitics: the Reader’s Digest and the construction of danger', Political Geography, 15/6-7 (1996) pp. 557-570.

${ }^{25}$ J. Sorenson, 'Mass media and discourse on famine in the Horn of Africa', Discourse \& Society 2/2 (1991) pp. 240-241.

${ }^{26}$ J. P. Sharp, 'Hegemony, popular culture and geopolitics: the Reader's Digest and the construction of danger’, Political Geography, 15/6-7 (1996) pp. 567.

${ }^{27}$ Mawdsley (not 24) pp. 523.

${ }^{28}$ G.O. Thuathail, 'An Anti-geopolitical Eye: Maggie O'Kane in Bosnia, 1992-93', Gender, Place \& Culture 3/2 (1996) pp. 171-186; A. Pinkerton, 'Journalists', in K. Dodds, M. Kuus and J. Sharp (eds.) Ashgate Research Companion to Geopolitics (London: Ashgate 2013) pp. 444. On anti/countergeopolitics, see S. Koopman, 'Alter-geopolitics: Other securities are happening', Geoforum, 42/3 (2011), pp. 274-284.

${ }^{29}$ D. Kelley, and R. Donway, 'Liberalism and free speech', in Judith Lichtenberg (ed.) Democracy and the mass media (Cambridge: Cambridge University Press 1990) pp. 66-101; K. Voltmer, 'The mass media and the dynamics of political communication in processes of democratization' in Katrin Voltmer (ed.) Mass media and political communication in new democracies (London: Routledge 2006), pp.1-20.

${ }^{30}$ G. O'Tuathail, and J. Agnew, 'Geopolitics and discourse: practical geopolitical reasoning in American foreign policy’, Political Geography 11/2 (1992) pp. 195.

${ }^{31}$ See P. Robinson 'Theorizing the Influence of Media on World Politics', European Journal of Communication, 16/4 (2001) pp. 523-543; B. Zelizer and S. Allen, 'Pool system' in Keywords in News \& Journalism Studies (Maidenhead: Open University Press 2010) pp.115. Much uncritical media coverage of the 2003 Iraqi war was the result of military information management, e.g. the 'pool system', used by the allies' governments. The US government's news management system was proven to be successful in censoring news coverage across news organizations and suppressing critical voices towards (and largely during) the war. For an alternative perspective, see for example D. Gregory, The Colonial Present: Afghanistan, Palestine, Iraq. Blackwell. ${ }^{32}$ T. McFarlane and I. Hay, 'The battle for Seattle: protest and popular geopolitics in The Australian newspaper', Political Geography 22/2 (2003) pp. 213. The political economy of the media also plays a major factor, see for example Herman and Chomsky's now classic Manufacturing Consent. Pantheon; A. Prat and D. Strömberg, 'The political economy of mass media', in Advances in Economics and Econometrics (2010). Cambridge University Press.

33 R. Entman 'Framing: Towards a clarification of a fractured paradigm', Journal of Communication, $43 / 4$ (1993) pp. 52; S. Iyengar, and A. Simon, 'News coverage of the Gulf crisis and public opinion. A study of agenda-setting, priming and framing', Communication Research, 20/3 (1993) pp.365-383.

${ }^{34}$ J. Blumler and M. Gurevitch The Crisis of Public Communication (London: Routledge 1995)

${ }^{35}$ Pinkerton and Sparke quoted by Pinkerton (note 27) pp. 448.

${ }^{36}$ J. P. Sharp, 'Hegemony, popular culture and geopolitics: the Reader's Digest and the construction of danger’, Political Geography, 15/6-7 (1996) pp. 561-562.

${ }^{37} \mathrm{~K}$. Voltmer, 'The mass media and the dynamics of political communication in processes of democratization' in Katrin Voltmer (ed.) Mass media and political communication in new democracies (London: Routledge 2006), p.8.

${ }^{38}$ Desktop journalism describes journalists' desk-bound practice. This practices leads to the reduction of professionalism as individuals need to do everything. Churnalism involves 'rapid repackaging', unchecked second-hand material (e.g. public relations and news agency sources) which leads to the lack of investigative journalism. See M. Palmer, 'International News from Paris and London-Based Newsrooms’ Journalism Studies. 9/5 (2008), pp.813-821; J. Lewis, A. 
Williams and B. Franklin, 'A compromised fourth estate? UK news journalism, public relations and news sources’ Journalism Studies 9/1(2008) pp. 1-20.

${ }^{39}$ J. G. Blumler 'Foreword: in Praise of Holistic Empiricism' in K. Brants and K. Voltmer (eds.) Political Communication in Postmodern Democracy (p. ix-xii) (Basingstoke: Palgrave Macmillan 2011) p.x. 'Mediatization' is to be differentiated from 'mediation' which describes 'the concrete act of communication by means of a type of media in specific social context'. S. Hjarvard, the Mediatization of Culture and Society (London and New York: Routledge, 2013), pp.19.

${ }^{40}$ Edward Herman and N. Chomsky, Manufacturing Consent: the Political Economy of the Mass Media (London: Vintage 1994); Shanto Iyengar, and R. Donald Kinder, News That Matters. Television and American Opinion (Chicago IL: University of Chicago Press 1987); P. Robinson 'Theorizing the Influence of Media on World Politics', European Journal of Communication, 16/4 (2001) pp. 523-543; Maxwell McCombs, Setting the agenda : the mass media and public opinion (Oxford: Polity 2004); G. Darren Lilleker, Key Concepts in Political Communication (Sage Publications: London, Thousand Oaks, New Delhi 2006)

${ }^{41}$ The increasingly converged the political sphere and media sphere are conceptualized from international relations (CNN effect) and political communications (symbiotic relationship between politician and journalist in contemporary packaged or PR-ized politics) approach. See E. Gilboa 'The CNN Effect: The Search for a Communication Theory of International Relations' Political Communication 22/1 (2005) pp. 27-44; Bob Franklin, Packaging politics (London: Arnold 1994); M. Gurevitch, and J. Blumler (1990) 'Political communication systems and democratic values' in Judith Lichtenberg (ed.) Democracy and the mass media (Cambridge, England: Cambridge University Press 1990) pp. 269-289.

${ }^{42}$ D. Atkinson and K and Dodds, K. 'Geopolitical traditions: a century of geopolitical thought' in K. Dodds, and D. Atkinson (eds.), Geopolitical Traditions. London: Routledge 2000) pp. 10; G. O'Tuathail, 'The Postmodern Geopolitical Conditions: States, Statecraft and Security at the Millennium', Annals of the Association of American Geographers 90/1 (2000) pp. 172. The media power during humanitarian crisis however needs to be more carefully considered based on different scenarios of policy certainty and media coverage. See P. Robinson, 'The Policy-Media' Interaction Model: Measuring Media Power during Humanitarian Crisis' Journal of Peace Research 37/5 (2000) pp. 613-633.

${ }^{43}$ B. Berelson cited by A. Hansen 'Content Analysis' in A. Hansen, S. Cottle, R. Negrine and C. Newbold, Mass Communication Research Methods. (Basingstoke: Palgrave Macmillan 1998) p.91; J. W. Tankard, 'The empirical approach to the study of media framing', in S. D. Reese, O. H. Gandy \& A. E. Grant (eds.) Framing public life (Mahwah, NJ: Lawrence Erlbaum 2001), pp. 95-106; R. M. Entman, J. Matthes and L. Pellicano, 'Nature, Sources and Effects of News Framing', in K. Wahl-Jorgensen and T. Hanitzsch (Eds.), The Handbook of Journalism Studies (New York and London: Routledge 2009) pp. 175-190.

${ }^{44}$ Entman (note 33) pp. 51-58.

${ }^{45}$ According to LexisNexis, The Major World Newspapers group 'contains over 40 full-text newspapers from around the world. These newspapers are generally regarded by the reading public as those giving the most comprehensive and reliable coverage of any topic, whether local, national, or international'. For a full list of these newspapers, see http://www.lexisnexis.com.ezproxy4.lib.le.ac.uk/uk/nexis/results/shared/sourceInfo.do?sourceId= F_GB01NBSimplSrch.CS00002698. Most of the newspapers (a few exceptions including the UK Daily Mirror were excluded in manual searches) in this group are 'broadsheets' which carry more serious and in-depth coverage of foreign news than 'tabloids' which feature more on simplification, sensation, personalization, gossip and scandal. Most of these broadsheets have large circulations, e.g. the New York Times has a daily circulation of 1.8 million. See http://www.nytimes.com/2013/05/01/business/media/digital-subscribers-buoy-newspapercirculation.html?_r=0, accessed 4 June 2013; H. Ornebring and M. Johnson, 'Tabloid journalism 
and the public sphere: a historical perspective on tabloid journalism', Journalism Studies 5/3 (2004) pp.283-295. Although the Major World Newspapers group has included a few East Asia based newspapers such as the Korea Herald, other newspaper titles are predominately Anglo. The findings presented here must be interpreted against this backdrop.

${ }^{46}$ The search criterion for 'food crisis' was 'three or more mentions'. Other search criteria include 'anywhere', 'in the headline', 'at the start', 'in the indexing', and 'major mentions'.

${ }^{47}$ Letters to the editors, news briefs and abstracts, duplicates and stories from tabloids were excluded in manual searches.

${ }^{48}$ Based on the FAO statistics. FAO, available from http://www.fao.org/worldfoodsituation/wfshome/foodpricesindex/en/, accessed 30 June 2012.

${ }^{49}$ J. Sorenson, 'Mass media and discourse on famine in the Horn of Africa', Discourse \& Society 2/2 (1991) pp. 240; Eion Devereux, Understanding the Media (London: Sage 2003) pp. 46.

${ }^{50}$ Main event frame is determined by 'the headlines, opening paragraphs and information and details dominant in the story', a variable adopted from Z. Peng, 'Framing the anti-war protests in the global village', International Communication Gazette 70/5 (2013), pp. 369.

${ }^{51}$ Many writers drew on the Malthusian fear, and warned about global food insecurity, e.g. Lester Brown's influential book Who will feed China? Wake-up call for a small planet. See Boland (note 14), pp. 55-76; Somerville et al (note 5)

${ }^{52}$ This is also part of the standard journalistic structure based on five Ws: Who, What, When, Where and Why.

${ }^{53} \mathrm{~N}$ (number), p(percentage). Based on variable Cul_all. This variable was created in the data analysis stage by combining Cul_1, Cul_2, Cul_3 and Pri_Cul. These percentages are read with more significance when taking into account the 'N/A' sub-frame $(n=680 / p=45.7 \%)$ which refers to no culprit identified.

${ }^{54}$ Here I focus on media blame on 'China and India' as this accusation was later refuted by authoritative institutions such as the FAO.

${ }^{55}$ There is a high level of similarity between the Toronto Star story and a story carried by the Guardian (UK) on 24 April 2008, especially how both stories start with the Reuters wire story about rice ration. The Guardian included more specific information ('four bags of rice'). Both added more information to make the story context-specific ('the global food crisis is hitting North American consumers' vs. 'The global food crisis reached the United States...'). The Guardian has not acknowledged its source (Reuters wire story), but readers can identify the same key facts edited by these two newspapers.

${ }^{56}$ Food and Agricultural Organisation (FAO) 'The State of Agriculture Commodity Markets 2009', available from < ftp://ftp.fao.org/docrep/fao/012/i0854e/i0854e.pdf>, accessed 15 February 2010; Department of Environment, Food and Rural Affairs (DEFRA) 'The 2007/08 Agricultural Price Spikes: Causes and Policy Implications (2010)’, available from $<$ http://archive.defra.gov.uk/foodfarm/food/pdf/ag-price100105.pdf>, accessed 4 February 2010. ${ }^{57}$ Pri_Cul is used to code 'culprit/s' that are explicitly indicated by the news stories as 'main', 'most important' cause/s, or Pri_Cul is coded when there is only one factor discussed.

${ }^{58}$ I. Hofman, and P. Ho, 'China's 'Development Outsourcing': A critical examination of Chinese global 'land grabs' discourse. The Journal of Peasant Studies, 39/1 (2012) p.1-48.

${ }^{59}$ See 'Rich and poor will both pay a high price for world food crisis', the Daily Telegraph (24 April 2008); 'From riches to rags', the Washington Times (7 May 2008); 'Year of hungry', the Independent (28 December 2008). Details vary in these stories. Some use 'SUV', others use '4x4'; some claim 'grain' is used for filling fuel tank, others specify that 'maize' is used.

${ }^{60}$ See 'Food shortages threaten gains against poverty', the Washington Times, 11 April 2008.

${ }^{61}$ The percentages again need to be interpreted against the backdrop of a high percentage of N/A $(\mathrm{n}=846 / \mathrm{p}=56.9 \%)$. This is because most news articles identified only one victim (Vic_1), and in the coding process, Vic_2 and Vic_3 were coded as 'N/A'. The 19\% 'the poor from 
underdeveloped countries' and 11\% 'world poor' identified are more significant when 'N/A' coded were taken into account.

${ }^{62}$ Sigfrido. B. Cáceres and Sophal Ear, 'The Geopolitics of China's Global Resources Quest', Geopolitics 17/1 (2012) pp.47-79; Mawdsley (note 24) pp. 509-529.

${ }^{63}$ China's partnership in Africa has been viewed as 'a threat to the international aid industry'. See M. Power, and G. Mohan, 'Towards a Critical Geopolitics of China's Engagement with African Development.' Geopolitics, 15/3 (2010) pp.462-495.

${ }^{64}$ See Sigfrido et al (note 65) pp.73.

${ }^{65}$ Ibid (note 72) pp.71.

${ }^{66}$ Mawdsley argues that it would be wrong to assume that Western investors in Africa which are also driven by profit are completely different from the Chinese counterparts, although they are indeed better bound by their charters, public pressure and voluntary agreements. See Mawdsley, (note 24) pp. 520.

${ }^{67}$ The expenditure on protein-rich food such as meat and dairy by the middle class Chinese have sharply risen in the past thirty years due to increasing disposable incomes, rapid urbanization and status-related dietary changes. China's demand for staple, wheat, is also linked to rising global wheat prices which has repercussions in wheat-importing country, Egypt. See H. L. Zhang and S. F. Song, 'Rural-urban Migration and Urbanization in China: Evidence from Time-series and Cross-section Analyses', China Economic Review. 14 (2003) pp. 386-400; National Bureau of Statistics of China, 'China Statistics Yearbook 2008 available from

$<$ http://www.stats.gov.cn/tjsj/ndsj/2009/html/D0304e.htm>; <http://www.stats.gov.cn/tjsj/ndsj/20 09/html/D0304e.htm>; <http://www.stats.gov.cn/tjsj/ndsj/2009/html/J0905e.htm>, accessed 15 June 2010;

Yunxiang Yan, 'McDonald's in Beijing: The Localization of Americana' in L. James Watson (ed.), Golden Arches East McDonald's in East Asia. (Stanford: Stanford University Press 2003) pp. 39-76; K. R. Curtis, J. J. Mccluskey, and T. I. Wahl, (2007) Consumer Preference for Western-style Convenience Foods in China. China Economic Review, 18 (2007) pp.1-14 and T. Sternberg, 'Chinese drought, bread and the Arab Spring', Applied Geography, 34 (2012) pp.519524.

${ }^{68}$ Heady and Fan (note 4) pp.386; F. Tao, M. Yokozawa, J. Liu, and Z. Zhang, Z. (2009) 'Climate change, land use change, and China's food security in the twenty-first century: an integrated perspective’, Climate Change 93 (2009) pp. 443.

${ }^{69}$ It is argued that the impacts of China's deepened relationship with Africa are mixed. It can be beneficial as China brings direct investment and aids, but it can be also threatening as China's involvements undercut local manufacturing. The 'land grab' claim is poorly supported by empirical evidence. See Mawdsley (note 24) pp. 509-529; M. Obwona, and E. Chirwa, 2006. Impact of Asian Drivers on SSA agriculture and food security 2006 Available from http://www.fanrpan.org/documents/d00324/SSA Agriculture.pdf, accessed 3 July 2012; I. Hofman, and P. Ho, “China's 'Development Outsourcing': A critical examination of Chinese global 'land grabs' discourse”. The Journal of Peasant Studies, 39/1 (2012) p.1-48; D. Brautigam's work on Western media's inaccurate coverage of China's aid money to Africa. China's African Aid: Transatlantic Challenges, 2008 Available from http://www.gmfus.org/doc/Brautigam0410aFINAL.pdf, accessed 22 May 2013

${ }^{70}$ D. A. Brautigam and X. Tang, "China's Engagement in African Agriculture: 'Down to the Countryside’”. China Quarterly 199 (2009): pp. 686-706.

${ }^{71}$ See Boland's (note 14) analysis.

${ }^{72}$ Dalby quoted by A. Boland, 'Feeding fears: competing discourse of interdependency, sovereignty and China’s food security’, Political Geography 19/1 (2000) pp. 61

${ }^{73}$ Tim. Lang and Erik. Millstone, The Atlas of Food: Who Eats What, Where and Why (London and New York: Routledge 2008); H. Charles, J. Godfray, I. R. Crute, L. Haddad, D. Lawrence, J. 
F. Muir, N. Nisbett, J. Pretty, S. Robinson, C. Toulmin, and R. Whiteley, 'The future of the global system' Philosophical Transactions of the Royal Society of Biological Sciences 365/?(2010) pp. 2769-2777; P. Ericksen 'Conceptualising food systems for global environmental change research' Global environmental Change 18/? (2008) pp. 234-245; Sternberg (note 70).

${ }^{74}$ Both Sigfrido and colleagues and Mawdsley's papers argue for a more collaborative approach to China's world expansion. See Sigfrido et al (note 65) pp.72-74; Mawdsley (note 24) pp. 523525.

${ }^{75}$ The term silent may have come from Michael Watt's well-known book Silent Violence: Food, Famine, and Peasantry in Northern Nigeria (1983 UCA Press), though this was not confirmed with Josette Sheeran.

${ }^{76}$ E.g. 'Food Crisis is Depicted As "Silent Tsunami”' The Washington Post (23 April 2008).

${ }^{77}$ See 'Global hunger prods nations; Outside aid proves too slow' the Washington Times 19 April 2008; “"Perfect storm” ravages Somalia; Global food crisis meets local chaos' the International Herald Tribune 17 May 2008.

78 “"The factors include population growth, changing dietary patterns, prosperity in countries like China and India, [diverting crops for] fuel and lower [food] reserves', Mr. Holmes said”. B. Pisik 'U.N. fears food price “crisis” will worsen; Seeks solution for long term' The Washington Times 15 April 2008.

${ }^{79}$ J. Herbert Gans, Deciding What's News: a study of CBS Evening News, NBC Nightly News, Newsweek, and Time (New York: Pantheon 1979); Blumler and Gurevitch (note 34); Manuel Castells, Communication Power (Oxford, New York: Oxford University Press 2009).

${ }^{80}$ http://www.rau.ac.uk/the-rau/governance-finance/governance-membership/professor-sir-johnbeddington, accessed on 5 June 2013.

${ }^{81}$ Trevor Morris and Simon Goldsworthy, PR - a Persuasive Industry? Spin, Public Relations, and the Shaping of the Modern Media (Basingstoke: Palgrave McMillan 2008) pp.125; Johan F. M. Swinnen, Pasquamaria Squicciarini and Thijs Vandemoortele, 'The food crisis, mass media and the political economy of policy analysis and communication', European Review of Agricultural Economics 38/3(2011), pp. 410; J. Sorenson, 'Mass media and discourse on famine in the Horn of Africa', Discourse \& Society 2/2 (1991) pp. 224-225.

${ }^{82}$ See B. Pisik 'U.N. fears food price “crisis” will worsen; Seeks solution for long term' from The Washington Times (15 April 2008); D. Blair 'World food crisis "here to stay”', the Daily Telegraph (London) (19 May 2008);

${ }^{83}$ W. A. Gamson and A. Modigliani (1989), 'Media discourse and public opinion on nuclear power: A constructionist approach', American Journal of Sociology 95/1 (1989) p.1-37; see also Entman (note 33) pp. 52.

${ }^{84}$ See A. Martin 'One Country's Table Scraps, Another Country's Meal' the New York Times 18 May 2008.

${ }^{85}$ See quote from a journalist from a UK national newspaper 'We've always been reliant on wire copy, but we use it a hell of a lot more these days - it's quite common for us to cut and paste a story off PA (Press Association), re-nose it a bit to mask where it's come from, and then put it out there as our own'. J. Lewis, A. Williams and B. Franklin, 'A compromised fourth estate? UK news journalism, public relations and news sources’ Journalism Studies 9/1(2008) pp. 42.

${ }^{86}$ Lewis and colleagues' research also found that news agency materials shaped news content, and their research found much higher percentages of news articles using agency and public relations (PR) materials. The difference in percentages found by this research and their research may be explained by the fact that this research did not attempt to identify unacknowledged PR materials. Due to limited resources, this research was unable to carry out a complex crosschecking of news stories with unacknowledged source materials, as this has been proven difficult even for a research team. However, this research did come across many news stories constructed with the same key ideas, comments and materials, even though there was no acknowledgement of 
the source. Lewis, A. Williams and B. Franklin, 'A compromised fourth estate? UK news journalism, public relations and news sources’ Journalism Studies 9/1(2008) pp. 1-20.

${ }^{87}$ The New York Times and the International Herald Tribune often print similar/identical stories. The Sydney Morning Herald and the Age printed identical stories on 18 June 2008. On 6 December, these two newspapers again printed almost identical stories, listing China's meat consumption (80 million ton per year) as one of the factors pushing up food prices 2007-08. 88 'Originality was not encouraged. Speed was... In London Agence France-Presse (AFP) correspondents rewrote Reuters' copy, as fast as they could, and the finished product ended up as part of the AFP news service. In Paris, we shamelessly rewrote Agence France Presse copy, serving it up as Reuters' fare.' M. Palmer, 'International News from Paris and London-Based Newsrooms’ Journalism Studies. 9/5 (2008), pp.814.

${ }^{89}$ Desktop journalism describes journalists' desk-bound practice. This practices leads to the reduction of professionalism as individuals need to do everything. Churnalism involves 'rapid repackaging', unchecked second-hand material (e.g. public relations and news agency sources) which leads to the lack of investigative journalism.

${ }^{90}$ See Pinkerton's analysis of 'attachment journalism' (note 27) pp.441-446; Somerville et al (note 5).

${ }^{91}$ See T. Weis, 'The Meat of the Global Food Crisis’, Journal of Peasant Studies 40/1 (2013) pp. 65-85.

${ }^{92}$ See K. Burnett, 'Trouble in the Fields: Governing after the Food Crisis and the Response of the Fair Trade and Food Sovereignty Movements. Geopolitics.

${ }^{93}$ L. Bennnet, 'Toward a Theory of Press-State Relations in the United States', Journal of Communication 40/2 (1990) pp.103-125.

${ }^{94}$ See D. Brautigam's work on Western media's inaccurate coverage of China's aid money to Africa. China's African Aid: Transatlantic Challenges, 2008 Available from http://www.gmfus.org/doc/Brautigam0410aFINAL.pdf, accessed 22 May 2013, p.5; Former foreign correspondent Ed Behr's book titled 'Anyone here been raped and speaks English?' reveals reductionist journalistic approach towards an African civil war. See D. Randall, The Universal Journalist ( $2^{\text {nd }}$ edition) (London: Pluto Press 2000) pp.55.

${ }^{95}$ The big Western news agencies (Agence France-Presse, Associated Press and Reuters) with hundreds of news bureaus and thousands of journalists worldwide dominate much of the information flow in the world communication system. Other media conglomerates such as the CNN also play important roles in homogenising world news. See Terhi Rantanen and Oliver Boyd-Barrett 'Global and national news agencies: threats and opportunities in the age of convergence’ in: Arnold de Beer and John C. Merrill (eds.) Global journalism: topical issues and media systems (Boston: Allyn \& Bacon 2008), pp. 33-47; Daya Thussu, International Communication: Continuity and Change (London: Arnold 2000) pp.150-166.

${ }^{96}$ See Pinkerton's analysis of 'attachment journalism' (note 27) pp.441-446.

${ }^{97}$ See Somerville et al (note 5).

${ }^{98}$ See Robinson (note 31).

${ }^{99}$ See Jason Dittmer and Klaus Dodds, 'Popular Geopolitics Past and Future: Fandom, Identities and Audiences’, Geopolitics 13/3 (2008) pp.437-457. 